\title{
EntreVista COM VAlter Hugo MÃE
}

ntrevista realizada por Penélope Eiko Aragaki Salles, aluna do

10 Programa de Estudos Comparados de Literatura de Língua La. Portuguesa, do Departamento de Letras Clássicas e Vernáculas da Universidade de São Paulo, no dia 03 novembro de 2016, no Teatro Eva Herz.

O entrevistado, Valter Hugo Mãe, é considerado um dos autores mais consagrados da literatura portuguesa da atualidade. Nos seus 20 anos de carreira literária, teve publicados livros em diferentes gêneros: poesia, romances, contos, livros infanto-juvenis. Sua obra tem sido aclamada tanto pela crítica literária quanto pelo público em geral. Ganhador do Prêmio José Saramago (2007) e Portugal Telecom (2012), o escritor português esteve no mês de novembro lançando o seu novo romance Homens Imprudentemente Poéticos, cuja história é ambientada num Japão antigo e conta um pouco a trajetória do artesão Itaro e suas desavenças com o oleiro Saburo.

Revista Crioula: É possível dizer que a semente do romance Homens Imprudentemente Poéticos surgiu a partir de seu contato com o Japão na filmagem do Sentido da Vida, o filme do Miguel Gonçalves Mendes?

Valter Hugo Mãe: Não. Quando estive com o Miguel no Japão, eu já estava a trabalhar no livro. O livro já existia em várias versões, inclusive. E eu visitei com ele a Floresta dos Suicidas, um lugar que era importante para o livro. E a gente discutiu muito sobre essa viagem, sobre a possibilidade de deslocarmos ao Monte Fuji para conhecermos esta floresta. Era algo que eu desconfiava que poderia entrar no meu livro, mas não estava certo. Queria muito ver, porque de início eu achava que talvez não fizesse sentido, porque para mim era fundamental que o livro acontecesse em Kyoto. E a Floresta dos Suicidas, eu creio, que fica no Monte Fuji, não tem nada que ver, em termos espaciais, com Kyoto. Então, de início, fiquei em dúvida de usar a floresta. Mas aí, depois de ter estado transgredido, eu pensei: vou assumir que é uma des- 
locação no tempo e no espaço, porque o meu livro passa-se ainda no nosso século XIX e por isso é uma ficção absoluta desta realidade num lugar onde ela não acontece, nunca aconteceu. Mas eu assumo isso, sobretudo, porque eu fiquei muito impressionado com a energia, com a dimensão espiritual do lugar e eu queria muito que meu livro passasse um pouco pela reflexão do suicídio. Os meus livros têm sempre uma questão com a morte, a morte é sempre um tópico. Fico com a sensação que eu quero ofender a morte assim, meio abusivamente, quero que ela se humilhe perante aquilo que nos faz.

Revista Crioula: Em outubro, a Porto Editora organizou um grande evento em celebração de seus 20 anos de carreira literária. Como foi revisitar essa trajetória?

Valter Hugo Mãe: Você sabe que fazer 20 anos de edição é, sobretudo, aliciante para que sirva de um ponto de partida. Parece meio doido ao fim de sete romances eu querer começar. Mas a sensação que eu tenho é que o mais valioso de se considerar e se celebrar nesta idade é exatamente a possibilidade de estar consciente de umas certas capacidades e verdadeiramente encontrar um grande livro, como se os livros anteriores pudessem ser uma breve visagem para o que pode vir a seguir. Gosto que tenham passados estes vinte anos, não porque eu acho que nesses vinte anos encontro o melhor que posso fazer ou o melhor que eu fiz, mas porque estes vinte anos são a preparação para fazer algo muito mais incrível. Então, eu quero muito que isto sirva como de facto oficina para livros maiores.

Revista Crioula: Nenhuma Palavra é Exata, o livro de ensaios sobre sua produção literária, também foi publicado neste evento comemorativo. Você costuma acompanhar as críticas, resenhas, dissertações e ensaios acadêmicos sobre a sua obra?

Valter Hugo Mãe: É muito difícil acompanhar porque as pessoas não enviam para mim. Muita gente não contacta, não diz, não avisa, então, eu fico sem saber. De vez em quando é muito surpreendente encon- 
trar textos sobre minha obra. Até já pensei em pedir, em colocar no Facebook declaradamente. Dizer: quando vocês fizerem algum trabaIho acadêmico, imprimam, tragam no momento em que me encontrar numa livraria. Seja onde for, tragam. Eu gostaria de ler, gostaria de guardar assim. Quando estive em setembro em Salvador, houve uma senhora que me trouxe uma tese de mestrado. É sobre A Máquina de Fazer Espanhóis. E houve também uma moça que me trouxe um artigo, um paper, talvez de 30 páginas. Eu fico muito curioso por ler. Aí não tem nem para Benjamim Moser, de que eu gosto muito. É muito importante para mim esse retorno e a verdade é que estou cada vez mais sensível ao retorno acadêmico. Nesse sentido em que a conversa acadêmica traz uma profundidade que escapa ao mundano. Então, eu consigo encontrar um retorno mais profundo, talvez, acerca dos meus livros. Torna-se muito gratificante.

Revista Crioula: Aproveitando sua fala, você acha importante que obras de autores contemporâneos, como você, sejam estudadas e pesquisadas na Universidade, mesmo que não sejam considerados canônicas?

Valter Hugo Mãe: Sim, o Agamben diz que nós sofremos a contingência de não sermos nossos contemporâneos. Ninguém é seu contemporâneo, porque nós, no momento em que estamos aqui no presente - inevitavelmente existimos sempre no presente - somos, sobretudo, resultado de um conhecimento passado. Parece que o que sabemos hoje, fechados nesta pequena sala conversando ou o que nós sabemos do mundo, está imediatamente obsoleto. Porque pode ter acontecido alguma coisa ou pode estar acontecendo alguma coisa que a gente não sabe. Porque nós só sabemos o momento anterior. Estamos sempre apenas conscientes de um certo momento anterior. Agora sendo isso uma contingência, eu me recuso a ficar passivo em relação ao meu tempo e, por isso, eu sei que o futuro vai ratificar, vai decidir a importância devida a cada obra. Mas eu me recuso a ficar passivo, esperando apenas pelo futuro. Quero que em todas as coisas e, acho fundamental que em todas as coisas, que nós estejamos ativos e capazes de 
tomar também uma decisão e, podemos arriscar falhando, errando. Presumindo que alguma coisa vai ser fundamental e eventualmente descobrindo depois que não, que estávamos errados. Mas eu prefiro errar e estar ativo a apenas simplesmente viver no puro ceticismo e na passividade, nessa coisa inoperante de achar que nós não contamos para a decisão do futuro. Porque eu acho que sim, nós contamos para a decisão do futuro.

Revista Crioula: As coisas que você menciona são importantes porque elas têm a ver com realmente pensar o momento de hoje e refletir sobre ele.

Valter Hugo Mãe: Já não se pode admitir, ainda que a gente possa ter na cabeça esta ideia de que somos, sobretudo, uma consciência do passado, que não somos nossos contemporâneos. Eu não aceitaria viver sem tentar e influir melhorando o meu cotidiano, o nosso cotidiano. E sou muito avesso, e cada vez mais avesso, ao indivíduo cético, cínico, que passa pelo mundo como se fosse desconfiado de si mesmo, como se não pudesse conceber que a sua própria conduta pode constituir de mais valia para a vida de alguém. E eu quero viver acreditando que a minha conduta e que a conduta das outras pessoas possam ser de mais valia para a vida de alguém. 